\title{
DETERMINATION OF HYDRODYNAMIC PARAMETERS OF THE SEALED PRESSURE EXTRACTOR
}

\author{
Nataliaya Kosulina ${ }^{1}$, Stanislav Kosulin ${ }^{2}$, Kostiantyn Korshunov ${ }^{1}$, Tetyana Nosova ${ }^{3}$, Yana Nosova ${ }^{3}$ \\ ${ }^{1}$ Kharkiv Petro Vasylenko National Technical University of Agriculture, Department of Biomedical Engineering and Theoretical Electrical Engineering, Kharkiv, Ukraine, \\ ${ }^{2}$ Kharkiv Medical Academy of Postgraduate Education, Department of Oncological Surgery Ray Therapy and Palliative Help, Kharkiv, Ukraine, ${ }^{3}$ Kharkiv National University \\ of Radio Electronics, Biomedical Engineering Department, Kharkiv, Ukraine

\begin{abstract}
The subject matter of the article: Sealed extractor with pressure. The goal of the work: determination of hydrodynamic parameters of the sealed extractor with pressure. As a result of the analysis of the technological process and equipment used in the factories for primary processing of wool, shortcomings and problems are identified and means for their elimination are proposed. It is proposed to use small-sized equipment to work on waste-free technology based on a hydrodynamic pressure extractor. Extraction as an efficient mass transfer process for removing organic components from aqueous solutions has the advantages of low operating temperatures and efficiency. The design features of the sealed pressure extractor are as follows: high angular velocities, the moment of inertia of rotating details, powerful pressure, the presence of nodes that provide a supply and discharge of liquids, tightness. The kinematic and geometric parameters of the rotor affect the sealed extractors' performance. In sealed extractors, the heavy fraction in the field of centrifugal forces will accumulate on a large radius of the inner side of the rotor and for its movement it is necessary to create an excess pressure at the extractor inlet.
\end{abstract}

Keywords: water extractor, primary processing of wool, fluid flow hydrodynamics, rotor of extractor, angular velocity of rotation

\section{OKREŚLANIE PARAMETRÓW HYDRODYNAMICZNYCH USZCZELNIONEGO EKSTRAKTORA}

\begin{abstract}
Streszczenie. Przedmiotem badań przedstawionych $w$ artykule jest ekstraktor ciśnieniowy. Celem pracy jest określenie jego parametrów hydrodynamicznych. W wyniku analizy procesu technologicznego i urzadzen stosowanych w fabrykach wstępnego przerobu wetny zidentyfikowano problemy $i$ zaproponowano sposoby ich eliminacji. Proponuje się wykorzystanie matogabarytowych urzadzeń do pracy $w$ technologii bezodpadowej opartej na hydrodynamicznym ekstraktorze ciśnieniowym. Ekstrakcja jako skuteczny proces przenoszenia masy do usuwania składników organicznych $z$ roztworów wodnych wykazuje zalety $w$ postaci niskich temperatur roboczych i efektywności. Cechy konstrukcyjne ciśnieniowego ekstraktora ciśnieniowego to duże prędkości kątowe, moment bezwładności obracających się części, wysokie ciśnienia, obecność węzłów zapewniających dopływ $i$ odprowadzanie cieczy oraz szczelność. W ekstraktorach ciśnieniowych na wydajność wplywaja parametry kinematyczne i geometryczne wirnika. $W$ zamkniętych ekstraktorach frakcja ciężka $w$ polu sit odśrodkowych będzie się gromadzić na dużym promieniu wewnętrznej płaszczyzny wirnika i do jej przemieszczenia konieczne jest wytworzenie nadciśnienia na wlocie do ekstraktora.
\end{abstract}

Słowa kluczowe: ekstraktor wody, pierwotna obróbka wełny, hydrodynamika przepływu płynów, wirnik ekstraktora, kątowa prędkość obrotowa

\section{Introduction}

Analysis of the work of the textile industry in recent years gives grounds to conclude that the decline in production continues, and the economic conditions of the operation of enterprises do not allow stopping the decline in production [17].

The technical level of the equipment installed at the factories for the primary processing of wool does not meet modern requirements, and the engineering industry of Ukraine does not produce machines and equipment for this industry [16].

Analysis of the technological process and equipment used for the primary processing of wool revealed the following significant disadvantages [6]:

- negative impact on the environment;

- energy intensity of production;

- material consumption;

- large overall and mass characteristics;

- poor fiber quality.

To eliminate these shortcomings, ways are outlined that, in our opinion, allow solving the listed problems, and to do this it is necessary:

- to develop a new waste-free technology for the primary processing of wool;

- to develop small-sized equipment for work on a waste-free technology based on a hydrodynamic pressure extractor with automated control from a computer/ACS TP

\section{Analysis of the latest achievements and publications}

The large number of various contaminants in industrial wastewater determines the numerous methods, methods, techniques and technological schemes used in their purification $[5,7,18,19]$.
The existing cleaning methods can be divided into five groups: mechanical group which involves averaging, aeration, settling, sedimentation in hydrocyclones, filtering, filtration; chemical (reagent) group which contains neutralization and filtration through active loading, coagulation, chemical precipitation and coprecipitation of harmful substances, oxidation and reduction; physical-chemical group which consists of extraction, evaporation, adsorption, ion exchange, electrocoagulation and electrolysis, flotation, crystallization; biological group which involves aerobic oxidation in bio-filters and in aeration tanks, anaerobic digestion in digesters; thermal group which involves vaporization and evaporation, waste water incineration, sludge drying incineration.

The considered methods, in turn, are divided into regenerative and destructive ones. Regenerative methods include most of the physicochemical methods, such as extraction, evaporation, adsorption, ion exchange, electrolysis, crystallization. The rest of the methods are essentially destructive, however, in some specific cases, they can be used to carry out regenerative treatment, that is, to extract useful substances from wastewater. A number of methods can be classified as widely used in the treatment of industrial wastewater. These are, first of all, settling, filtering, averaging, neutralization, chemical precipitation, biological treatment $[6,8,19]$.

The practice of recent years has included the method of flotation for the purification of waste- water from the primary processing of wool $[2,12,20]$. The treatment of wastewater by the flotation method has a number of advantages, which predetermines the prospects of this method and the possibility of its use for the purification of both industrial and domestic wastewater [1].

The disadvantages of the reagent-floatation technology include the need to implement the flotation process at low $\mathrm{pH}$ values up to $4.2 \ldots 4.5$, it requires the use of acid-resistant equipment not only in the treatment facilities block, but also in the sludge treatment block [11]. 
Analysis of the literature and the results of our own research showed that the most acceptable method of wastewater treatment with their return to the circulating system can be the use of centrifugation and electro-flotation [10,14].

The main stages of the electro-flotocoagulation process are:

1) Generation of an electrolytic coagulant;

2) Electrolytic gas generation;

3) Coagulation of impurities;

4) Fixation of electrolytic gas on the surface of coagulated particles (formation of flotation complexes) [13, 15].

A significant disadvantage of electro-flotocoagulation is the processes of passivation of the surface of soluble electrodes and the adsorption of impurities on them.

Therefore, maintaining the optimal current density is a prerequisite for the operation of the electro-coagulator [9].

The performed analysis shows that the degree of purification depends on many factors, the main of which are: current density, processing time, height of the liquid layer, temperature of the liquid, and the degree of dissociation of water into ions, estimated by the $\mathrm{pH}$ value.

The design features of the sealed pressure extractor are high angular velocities, the moment of inertia of rotating parts, high pressures, the presence of nodes that ensure the supply and removal of liquids, and tightness. Automated control is assumed by means of a computer/ACS TP.

\section{Main research material}

The purpose of the work is to determination of hydrodynamic parameters of the sealed pressure extractor.

The main elements of equipment for the primary processing of wool (PPW) are: a unit for washing and pressing wool, equipment for water regeneration and fat release, a drying unit, an automated control system for complex washing of wool Fig. 1 shows the block diagram of the primary processing of wool.

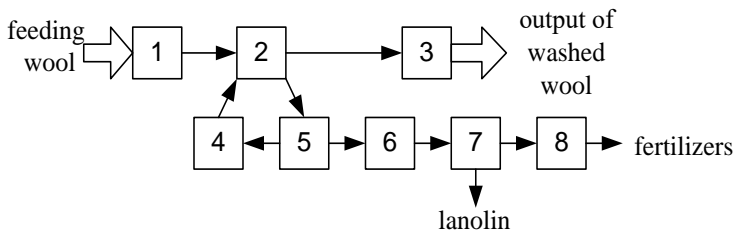

Fig. 1. Block diagram of the primary processing of wool: 1 -dispenser; 2 -washing machine; 3 - drying machine; 4 - water preparation tank; 5 - waste water regenerator; 6 -fat accumulator; 7 -separator; 8 -fertilizer drying chamber

The process of wool processing is automated by the automated process control system. To regulate the pressure of the fractions, select the rotor speed, take into account design features and obtain the best performance, it is necessary to understand the processes taking place directly in the sealed pressure extractor.

The hydrodynamics of the flow of two immiscible liquids through the extractor rotor equipped with perforated cylinders is not fully studied. Experimental work made it possible to establish only a qualitative picture of the hydrodynamic process and the influence of individual factors on the nature of its course.

When the fluid rotates together with the rotor, the pressure at any point located inside the working volume is determined by the angular velocity of rotation of $\omega$ rotor, the volumetric weight of the liquid $\gamma$ and the radius of the location of this point $R_{i}$ from the axis of rotation [6, 8]. The calculation formula for determining the pressure will be as follows:

$$
P_{i}=\frac{\gamma \omega^{2} R_{i}^{2}}{2 g}
$$

If the inner cavity of a rotating rotor is limited by cylinders with radii $R_{n}$ and $R_{k}$, then the calculation is performed according to formula 2 :

$$
P_{i}=\frac{\gamma \omega^{2}\left(R_{k}^{2}-R_{n}^{2}\right)}{2 g}
$$

To determine the hydrodynamics during the rotation of the rotor, a program (GIDRAVL-1) was developed. Figures 2 and 3 present graphs showing the relationship between rotor diameter, rotor speed and developed pressure.

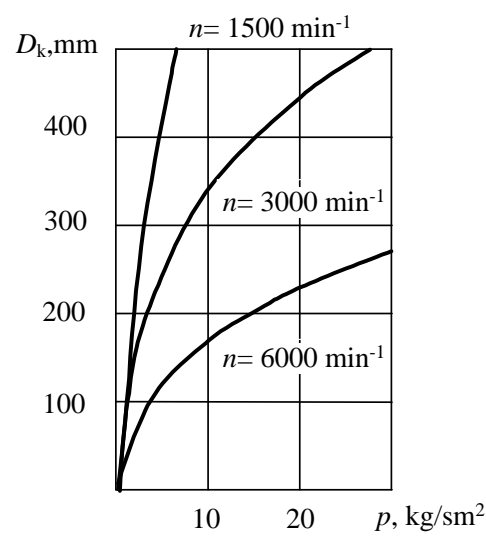

Fig. 2. Relationship between rotor diameter and developed pressure

The rotor of the extractor is cylindrical. With continuous feeding of the extractor with heavy and light fractions, counter axial flows are created in the rotor, closed in the annular space between the rotor cylinders.

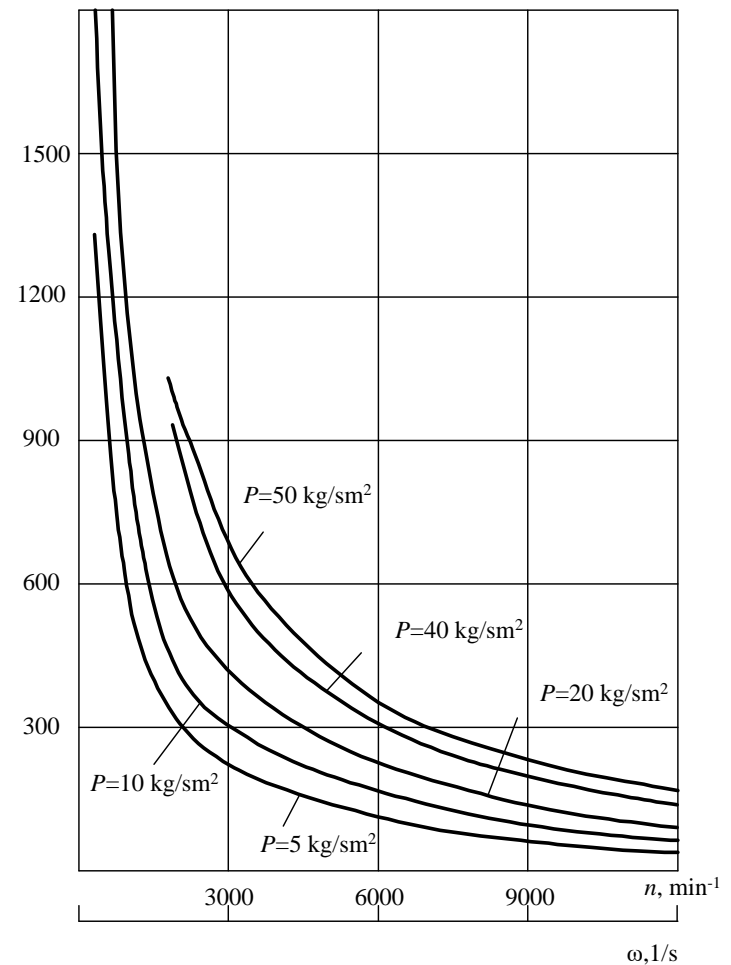

Fig. 3. The relationship between the diameter of the rotor, the frequency of its rotation and the developed pressure

Let us apply the Bernoulli equation for a cylindrical flow in the field of centrifugal forces. Its form is for the case when the liquid is only under the influence of centrifugal forces:

$$
\frac{\omega^{2}\left(R^{2}-r^{2}\right)}{2}+\frac{p}{\gamma}+\frac{V^{2}}{2}=\text { const }
$$


Consider the movement of fluid from one section to another. Fig. 4 shows a section of flow $1-2$ in a centrifugal field.

The equation for the real fluid flow along the rotor cylinders will be:

$$
\frac{\omega^{2}\left(R^{2}-r_{1}^{2}\right)}{2}+\frac{p_{1}}{\lambda}+\frac{\alpha_{1} V_{1}^{2}}{2}=\frac{\omega^{2}\left(R^{2}-r_{2}^{2}\right)}{2}+\frac{p_{2}}{\lambda}+\frac{\alpha_{2} V_{2}^{2}}{2}+h,
$$

where $h$ is the loss of specific energy of the flow between the considered sections; $\alpha$ are Coriolis coefficients in the considered sections.

Based on the above equations, we obtain the formula for the liquid outflow from a rotating cylinder.

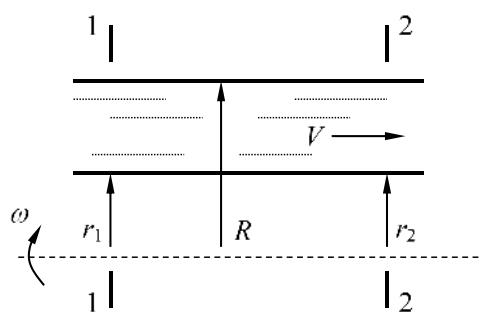

Fig. 4. Section of flow $1-2$ in a centrifugal field

Let a liquid flow out of a rotating cylinder through a hole in the wall under a constant pressure.

To determine the rate of fluid outflow, we use equation (4), composing it for cylindrical surfaces of radii $R$ (outer) and $r_{0}$ (inner) fluid layer. Then, neglecting the magnitude of the velocity on the free surface of the liquid and taking the Coriolis coefficient equal to unity, and also assuming that the pressure in the sections is equal to atmospheric, we obtain:

$$
\frac{\omega^{2}\left(R^{2}-r_{0}^{2}\right)}{2}=\frac{V^{2}}{2}
$$

where from

$$
V=\omega \sqrt{R^{2}-r_{0}^{2}}
$$

If the rotating cylinder is completely filled with liquid, then:

$$
V=\omega R=U_{0}
$$

Thus, when the cylinder is filled, the rate of fluid outflow through the hole is equal to the circumferential speed of rotation of the cylinder.

We accept the following assumptions: $p_{2}$ is equal to zero, $p_{l}$ is not equal to zero, $\alpha=1$

$$
\psi=\frac{h}{p}
$$

To determine the flow rate through the hole in the cylinder, we use the formula:

$$
W=\varphi \varepsilon S \sqrt{\frac{2 p(1-\psi)}{\gamma}}+\omega^{2}\left(R^{2}-r_{0}^{2}\right)
$$

where $S$ is the cross-sectional area of the hole, $\varphi$ is the velocity coefficient, $\varepsilon$ is the compression coefficient of the jet.

The average value of the potential and kinetic energy per unit mass of the liquid flowing through the flow section, referred to the conditional surface, is called the specific energy. The specific energy in a rotating cylinder is expressed by the equation:

$$
E_{p}=\frac{1}{2} \omega^{2}\left(R^{2}-r_{0}^{2}\right)+\frac{p}{\gamma}+\frac{\alpha V^{2}}{2}
$$

Neglecting atmospheric pressure, we obtain the following expression for the specific energy referred to the inner surface of a rotating cylindrical rotor:

$$
E_{0}=\frac{1}{2} \omega^{2}\left(R^{2}-r_{0}^{2}\right)+\frac{\alpha V^{2}}{2}
$$

The volumetric velocity through the entire cross-section of the annular flow:

$$
V=\frac{\pi\left(p_{1}-p_{2}\right)}{\mu L} \int_{r}^{R}\left(\frac{1}{2}\left(R^{2}-r^{2}\right)+r_{0}^{2} \ln \frac{r}{R}\right) r d r
$$

where $\mu$ is the dynamic coefficient of viscosity $\left(\mathrm{nsec} / \mathrm{m}^{2}\right)$.

After integration, transformations and reductions, we find the volumetric velocity $\left(\mathrm{m}^{3} / \mathrm{sec}\right)$ :

$$
V=\frac{\pi\left(p_{1}-p_{2}\right)}{\mu L}\left(\frac{R^{4}}{4}+\frac{3}{4} r_{0}^{4}-R^{2} r_{0}^{2}-r_{0}^{4} \ln \frac{r_{0}}{R}\right)
$$

\section{Conclusions}

The above calculation formulas describe the processes occurring in sealed extractors. The performance in these units is influenced by the kinematic and geometric parameters of the rotor. In sealed extractors, the heavy fraction in the field of centrifugal forces will accumulate on a large radius of the inner plane of the rotor and for its movement it is necessary to create excess pressure at the inlet of the extractor.

The results obtained make it possible to accurately compose algorithms for the operation of a computer/ACS TP that control the process of cleaning wool and automatic control systems for the sealed pressure extractors. As well as supervisory control and data acquisition (SCADA) systems, emergency protection systems (ESD) and other smaller control systems (for example, systems based on programmable logic controllers (PLC)) $[3,4]$. The automated process control system of the wool cleaning process has a unified operator control system for the technological process in the form of several control panels, means for processing and archiving information about the process, typical automation elements: sensors, control devices, and actuators [21, 22]. Industrial networks are used for information communication of all subsystems.

In the ACS TP system of the water purification process after wool washing, there was a consistent increase in the complexity of the tasks facing the control systems from the control of individual sealed pressure extractors and parameters, to the automation of the process as a whole, and the automation of control systems. This makes it possible not only to carry out effectively management and control in the production area, but also to eliminate partially the influence of the human factor in management, which helps to avoid mistakes. Currently, the issues of increasing the autonomy of the ACS TP of the water purification process after wool washing, the redistribution of functions in the direction of increasing the load in decisionmaking at the ACS are relevant. In this case, the issues of developing the intellectual component of the automated process control system in the direction of creating algorithms for responding in real time to emerging critical situations during water purification in the process of washing wool are relevant.

\section{References}

[1] Aksenko A.A. et al.: A. c. 914506 (USSR). Apparatus for electrochemical purification of contaminated liquid. B.I. 11/1982

[2] Arterchuk A. G., Burchenko G. M., Zhurkov V. S.: Purification of oil-emulsion waste water from machine-building enterprises by the method of electrochemical coagulation. Inform. leaflet 102, 1974.

[3] Avrunin O. et al.: Development of up-to-date laboratory base for microprocessor systems investigation. 2009 19th International Crimean Conference Microwave \& Telecommunication Technology, Sevastopol 2009, 301-302.

[4] Avrunin O. G. et al.: Experience of Developing a Laboratory Base for the Study of Modern Microprocessor Systems. Proceedings of I International Scientific and Practical Conference "Theoretical and Applied Aspects of Device Development on Microcontrollers and FPGAs" MC\&FPGA-2019, Kharkiv, Ukraine, 2019, 6-8.

[5] Bateup B. O.: Clean green wool. Top-Tech '96: a CSIRO conference, Geelong 1996, 93-95.

[6] Demidov A. V.: Development and research of a roller device for increasing the efficiency of wool spinning after washing. Autoreferral of the doctoral thesis. Ivanovo 2005

This is the specific energy of the section. 
[7] Lupikov V. S.: Obrupting the method of measuring electrical penetration for drying with an electro-magnetic field. Bulletin of the National Technical University "Kharkiv Polytechnic Institute" 4, 2011, 131-134.

[8] Muntyan V.A.: Analysis of technological processes and devices for primary processing of wool. Energy saving, energetics, energy audit 1(71), 2010, 62-65.

[9] Mykhaylova L. M. et al.: Acoustic vibrations hydrodynamic emitter parameter determination. Telecommunications and Radio Engineering 79(3), 2020, 231-248 [https://doi.org/10.1615/TelecomRadEng.v79.i3.50]

[10] Nazaryan M. M. et al.: A. c. 710988 (USSR). Apparatus for electrochemica cleaning of contaminated liquid. B.I. 3/1980.

[11] Nazaryan M. M. et al.: A. c. 644738 (USSR). Apparatus for electrochemical cleaning of contaminated liquid. B.I. 4/1979.

[12] Nazaryan M. M., Efimov V. T., Mataev A. R. et al.: A. c. 555056 (USSR) Method of automatic regulation of electrochemical wastewater treatmen processes. B.I. 15/1977.

[13] Nazaryan M. M. et al.: A. c. 688445 (USSR). Apparatus for electrochemical cleaning of contaminated liquids. B.I. 36/1979.

[14] Nazaryan M. M. et al.: A. c. 827408 (USSR). Apparatus for electrochemica cleaning of contaminated liquid. B.I. 17/1981

[15] Nazaryan M. M. et al.: A. c. 899488 (USSR). Method of automatic regulation of processes of electrochemical purification of contaminated liquid. B.I. 3/1982.

[16] Potapskiy P. V., Mikhailova L. N.: Analysis of the mathematical mode of heating wool in bales by electromagnetic energy. Eastern European Journal of Advanced Technologies 86/2009, 115-119.

\section{D.Sc. Nataliaya Kosulina}

e-mail: kosnatgen@ukr.net

Doctor of Technical Sciences, Professor, Department of Biomedical Engineering and Theoretical Electrical Engineering, Kharkiv Petro Vasylenko National Technical University of Agriculture, Head of Department, Ukraine. Research interests: theoretical fundamentals of electrical engineering, electromagnetic field theory, methodology of scientific research, biomedical engineering, information electrical technologies in agrarian and industrial complex.

http://orcid.org/0000-0003-4055-8087

\section{M.Sc. Stanislav Kosulin}

e-mail: kosulinmd@gmail.com

Assistant department of Oncological surgery ray therapy and palliative help, KhMAPE (Kharkiv Medical Academy of Postgraduate Education), Ukraine. Research interests: electromagnetic field theory, biomedical engineering, information electrical technologies in agrarian and industrial complex.

\section{http://orcid.org/0000-0003-0791-0034}

\section{M.Sc. Kostiantyn Korshuno}

e-mail: hkostn@ukr.net

Postgraduate student, Department of Biomedical Engineering and Theoretical Electrical Engineering, Kharkiv Petro Vasylenko National Technical University of Agriculture, Ukraine. Research interests electromagnetic field theory, biomedical engineering, information electrical technologies in agrarian and industrial complex.
[17] Rogachev N. V., Vasilyeva L. G., Timoshenko N. K. et al.: Wool. Primary processing and market. Editors: N. K. Timoshenko. VNIIMPRASKHN, Moscow 2000.

[18] Rogachev N. V.: New in the technology of primary processing of wool. Sat. Technologies for primary processing of wool. Nevinnomyssk 1990, 17-27.

[19] Rogachev N. V.: Waste water treatment and wool modernization. Textile industry $21,1976$.

[20] Semenets V. et al.: Determination of parameters of plane hydrodynamic radiator of acoustic vibrations. Radiotekhnika: All-Ukr. Sci. Interdep. Mag 196, 2019, 167-179.

[21] Semenets V. et al.: Trends in Training Modern Technicians. First Internationa Scientific and Practical Conference "Theoretical and Applied Aspects of Device Development on Microcontrollers and FPGAs" MC\&FPGA-2019, Kharkiv, 2019 [https://doi.org/10.35598/mcfpga.2019.013]

[22] Semenets V.: Technical aspects for development laboratory base for learning FPGA and microcontroller systems. 10th International Conference The Experience of Designing and Application of CAD Systems in Microelectronics, Lviv-Polyana, Ukraine, 2009.

\author{
Ph.D. Tetyana Nosova \\ e-mail: gryshkov@imp.uni-hannover.de
}

$\mathrm{Ph}, \mathrm{D}$, associate professor, Kharkiv National University of Radio Electronics, Biomedical Engineering Department, Kharkiv, Ukraine. Research Interests: biomedical signal processing and images, functional diagnostics of musculoskeletal system.

http://orcid.org/0000-0003-4442-8001

\section{Ph.D. Yana Nosova
e-mail: yana.nosova@nure.ua}

$\mathrm{PhD}$, Senior Lecturer of the Department of Biomedical Engineering, Kharkiv National University of Radio Electronics, Ukraine. As part of the team of author of the patent "Device for the testing of respiratory disorders of smell" was awarded the diploma of the winner of the All-Ukrainian contest "Invention of the Year - 2016" in the nomination "Best invention in Kharkiv region". Research Interests: biomedical signal processing and images.

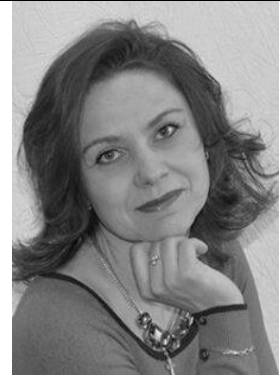

http://orcid.org/0000-0003-4310-5833

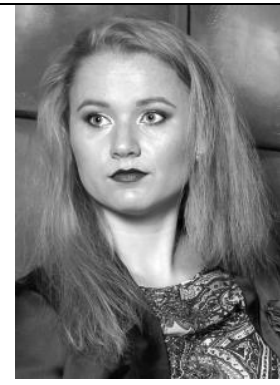

otrzymano/received: 8.05 .2021 